\title{
Investigation of NOx Emissions From Euro-IV Diesel Buses Using PEMS
}

\author{
L.J. Hao \\ State Key Laboratory of Automotive Simulation and Control \\ Jilin University \\ Changchun, China \\ School of Mechanical Engineering \\ Beijing Institute of Technology \\ Beijing, China \\ J.D. Guo \\ School of Mechanical Engineering \\ Beijing Institute of Technology \\ Beijing, China
}

\author{
Q. Liang \\ School of Mechanical Engineering \\ Beijing Institute of Technology \\ Beijing, China \\ Y.S. Ge \\ School of Mechanical Engineering \\ Beijing Institute of Technology \\ Beijing, China
}

\begin{abstract}
In this study, gaseous pollutants from three Euro-IV diesel buses equipped with urea selective catalytic reduction (SCR) system were investigated using portable emission measurement system (PEMS) in real world operating conditions. A work-based window method was applied to calculate on-road brake-specific oxides of nitrogen (NOx) emissions for the diesel buses. The emission test results showed that the Brake-Specific NOx (BSNOx) emission was significantly higher than the diesel engine corresponding legislation limit because the urea SCR system was not activated or not at optimal operation state under low exhaust temperature condition when the diesel buses run at low average vehicle speed.
\end{abstract}

Keywords-diesel bus; Selective Catalytic Reduction (SCR); Work-based Window Method; Portable Emissions Measurement System (PEMS); NOx Emission

\section{INTRODUCTION}

In big cities, diesel buses have aroused more and more concerns due to their negative effects on humans' health and environment especially for their NOx and PM emissions. Onroad measurement using PEMS is a very practical way to investigate the real-world emissions generated from the heavy duty vehicle (HDV) and evaluate the difference between the engine certification cycles and on road operating conditions[1,2]. Using PEMS for HDV emissions testing helps to eliminate the need for an expensive emission testing facility and the requirement to remove the engine from vehicle and install the engine on an engine dynamometer test bed.

Euro-IV diesel buses with urea SCR system are widely used in Beijing. In our previous studies [3-5], plenty of Onroad emission measurements on diesel buses were carried out. The testing of diesel buses both under real-world driving conditions and over the ETC, ESC and WHTC brought forth essential problems regarding the in use NOx emissions of modern diesel buses, since they complied with the corresponding emission standards for the type-approval test, but they usually go beyond the criteria limits when tested under real-world driving conditions. Considering that the HDV engine is usually run at low loads and low speeds and in order to compensate the considerable discrepancies between engine certification cycles and real-world driving conditions, Beijing Municipal Environmental Protection Bureau initiated and issued the Beijing local emission standard DB11/9652013[6], which presents the emission measurement methods and the NOx standard limit.

In this study, gaseous pollutants from three Euro-IV diesel buses equipped with urea selective catalytic reduction (SCR) system were investigated with portable emission measurement system (PEMS) in real world operating conditions. A workbased window method was applied to calculate on-road brakespecific oxides of nitrogen (NOx) emissions for the diesel buses. And the emission test results were discussed and analyzed in this paper.

\section{METHODS}

\section{A. Tested Vehicles and Routes}

Three Euro-IV diesel buses with V-based SCR systems were selected and tested in this study. The characteristics of the diesel buses used for this emission test are summarised in Table 1. 
TABLE I. TEST VEHICLE CHARACTERISTICS

\begin{tabular}{|c|l|l|l|}
\hline Type & \multicolumn{3}{|c|}{ Euro-IV Diesel bus } \\
\hline Bus No & 1 & 2 & 3 \\
\hline After treatment & $\begin{array}{l}\text { SCR (V- } \\
\text { based) }\end{array}$ & $\begin{array}{l}\text { SCR (V- } \\
\text { based) }\end{array}$ & $\begin{array}{l}\text { SCR } \\
\text { based) }\end{array}$ \\
\hline Mileage (km) & 67,232 & 41,991 & 54,785 \\
\hline Curb weight (kg) & 11,200 & 11,200 & 11,200 \\
\hline GVWR (kg) & 17,500 & 17,500 & 17,500 \\
\hline Cargo (kg) & 3000 & 3000 & 3000 \\
\hline $\begin{array}{c}\text { Overall length } \\
\text { (m) }\end{array}$ & 12 & 12 & 12 \\
\hline Cylinders & 6 & 6 & 6 \\
\hline Displacement (L) & 8.4 & 8.4 & 8.4 \\
\hline $\begin{array}{c}\text { Fuel injection } \\
\text { Direct } \\
\text { injection }\end{array}$ & $\begin{array}{l}\text { Direct } \\
\text { injection }\end{array}$ & $\begin{array}{l}\text { Direct } \\
\text { injection }\end{array}$ \\
\hline Max power (kW) & 228 & 228 & 228 \\
\hline
\end{tabular}

Three buses were chosen from the same bus fleet and had similar distances travelled, and the engines were made by the same manufacturer and had similar maintenance status.

Emission Measurements were carried out while the buses were driven in real-world conditions along their routine routes in urban area. And the buses stopped at each bus station as they did during routine services, but no passengers were on the buses, their daily passengers and cargos were substituted with a number of barrels of water placed inside the buses to attain approximately the same total vehicle weight.

\section{B. Equipment and Instruments}

A SEMTECH-DS analyzer (Sensors. Inc) was used for the on-road studies of gaseous emissions from diesel buses. The SEMTECH-DS analyzer uses a non-dispersive infrared (NDIR) unit for measurements of $\mathrm{CO} 2$ and $\mathrm{CO}$, a heated flame ionization detector (HFID) for THC, and a non-dispersive ultraviolet (NDUV) module for NO and NO2 measurements[7]. A global positioning system receiver was utilized to obtain latitude, longitude and altitude of vehicle's position, and the bus travel speed was calculated from these values. Temperature, pressure and relative humidity were also measured by a weather probe and recorded for later use. A four-inch steel tube exhaust flow meter (EFM) was utilized to measure the exhaust flow rate and exhaust temperature simultaneously. Sample gas was inducted into the analyzer by a heated sample line, which was heated and maintained at $190^{\circ} \mathrm{C}$ to minimize the loss of hydrocarbons. Before each test, a series of preparing procedures were performed, including warming-up the engine and SEMTECH-DS, calibration and leak check for the measurement devices.

Based on the exhaust flow rate and the concentrations and densities of various exhaust gas components, the instantaneous mass emission rate of different exhaust pollutants can be calculated.

\section{Work-Based Window Method}

A work-based window method was adopted to calculate inuse brake specific oxides of nitrogen (BSNOx) emissions for the tested buses. During in use emission test, the bus engine's speed and torque are read from the engine's electronic control unit, and along with time, are used to calculate instantaneous engine power for each second of the test, and then the instantaneous engine power is summed until the target amount of work is obtained [6]. Based on Beijing local emission regulation DB11/ 965-2013, the work in the determined window should be equal to the theoretical European Transient Cycle (ETC) work. The Brake-specific NOx emission is calculated as the sum of the grams of NOx emitted over the interval divided by the total work. The BSNOx result can be compared with the NOx legislation limit determined in DB11/ 965-2013, and applied to assess the emissions level of the tested vehicle.

\section{RESUltS AND DisCUSSION}

The BSNOx emissions of the three diesel buses calculated as functions of bus cruise speed were obtained and depicted in Fig.1, which clearly showed that the BSNOx emissions calculated with work-based window method were much higher than Euro IV ETC NOx limit under the average speed of 10 $\mathrm{km} / \mathrm{h}$. With the increase of vehicle speed, the BSNOx emissions decrease obviously. Only after the vehicle cruise speed is higher than $25 \mathrm{~km} / \mathrm{h}$, the BSNOx emission can meet the Euro IV ETC NOx legislation limit.

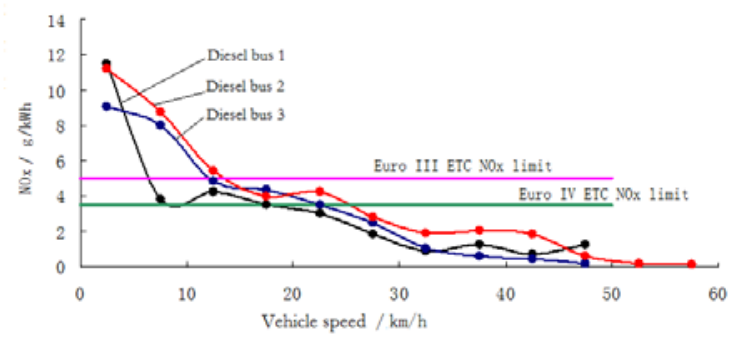

FIGURE I. THREE DIESEL BUSES' BSNOX EMISSIONS AS FUNCTIONS OF BUS CRUISE SPEED

Heavy-duty diesel engines are certified on the engine dynamometer test bench over the legislated test cycles, such as the European Transient Cycle (ETC) or Federal Test Procedure (FTP). ETC and FTP are transient engine dynamometer cycles with setpoints calculated on the basis of engine speed and engine torque. Most of the setpoints for ETC and FTP are located at high engine speed and engine load area, and the engine exhaust temperature during ETC and FTP testing is high enough that the urea SCR system can be activated and works at an optimal operation state. On the contrary, in real world driving conditions the diesel bus speed is low due to traffic jam, and the engine output power is small, so the engine exhaust temperature is much lower, the urea SCR system does work or work at a very low efficiency.

Fig.2 showed the tested travel speed and the exhaust temperature profiles of the No.1 diesel bus as functions of time during the morning rush hours. Although the instantaneous speed of the diesel bus can reach as high as $40 \mathrm{~km} / \mathrm{h}$, the bus experienced frequent stop-and-go actions, and the average travel speed during this trip was only $6.53 \mathrm{~km} / \mathrm{h}$, the exhaust temperature was below $200^{\circ} \mathrm{C}$ most of the time. Under $200^{\circ} \mathrm{C}$ the urea SCR system is not in optimal operation condition and cannot clean NOx component efficiently. 


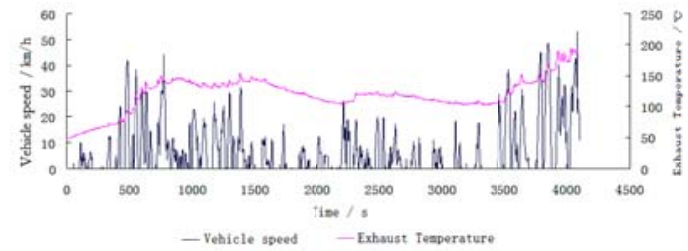

FIGURE II. THE DIESEL BUS TRAVEL SPEED AND EXHAUST TEMPERATURE PROFILES DURING THE MORNING RUSH HOURS

According to Beijing local emission regulation DB11/ 9652013, the three diesel buses were subjected to the required inuse testing to check their NOx emissions levels.

Based on our former studies on the average speed of the urban bus at rush hours within the Fifth Ring Road in Beijing, the average vehicle speed is less than $15 \mathrm{~km} / \mathrm{h}$. So we selected three traffic congestion levels, Vehicle speed $<10 \mathrm{~km} / \mathrm{h}$, $10 \mathrm{~km} / \mathrm{h}<$ Vehicle speed $<20 \mathrm{~km} / \mathrm{h}$, and $20 \mathrm{~km} / \mathrm{h}<$ Vehicle speed. The Fig.3 showed the average BSNOx emissions of the three diesel buses run at different congestion levels (Vehicle speed $<10 \mathrm{~km} / \mathrm{h}, \quad 10 \mathrm{~km} / \mathrm{h}<$ Vehicle speed $<20 \mathrm{~km} / \mathrm{h}$, and $20 \mathrm{~km} / \mathrm{h}<$ Vehicle speed).

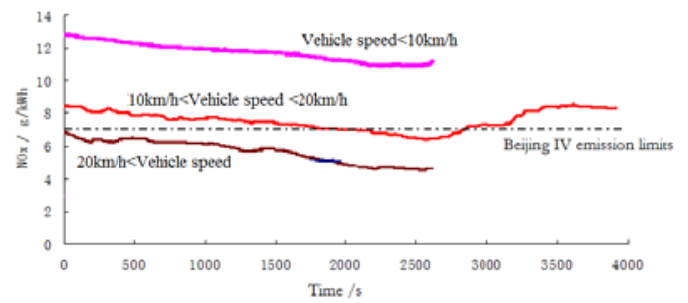

FIGURE III. THE AVERAGE BSNOX EMISSIONS OF THE THREE DIESEL BUSES RUN AT DIFFERENT TRAFFIC CONGESTION LEVELS

The on road BSNOx emissions increased when the diesel bus speed slowed down due to traffic jam, and the engine output power decreased, so the resulted exhaust temperature was lower, the working efficiency of the urea SCR system also decreased or the urea injection stopped.

\section{CONCLUSIONS}

In this study, NOx pollutants from three Euro-IV diesel buses were investigated with PEMS in real road driving conditions. A work-based window method was applied to calculate on-road brake-specific oxides of nitrogen (NOx) emissions. The emission test results showed that the BSNOx emission was significantly higher than its corresponding diesel engine legislation limit because the real world operation states of the bus engine is different from the engine type-approval cycles. When working in real-world driving conditions, the bus engine is usually run at low loads and low speeds and the exhaust temperature is so low that the urea SCR system is not activated or not at an optimal operation state, that causes the BSNOx emission increased. Effective steps must be taken to optimize the engine operation process, power-train matching and the SCR system efficiency.

\section{ACKNOWLEDGEMENTS}

This work was supported by Foundation of State Key Laboratory of Automotive Simulation and Control.

\section{REFERENCES}

[1] Chen, C., Huang, C., Jing, Q., et al. On-road emission characteristics of heavy-duty diesel vehicles in Shanghai. Atmospheric Environment, 41: pp.5334-5344, 2007.

[2] DURBIN T D, JOHNSON K, COCKER D R, III, et al. Evaluation and comparison of portable emissions measurement systems and federal reference methods for emissions from a back-up generator and a diesel truck operated on a chassis dynamometer. Environmental Science \& Technology, 41(17): pp.6199-6204, 2007.

[3] Guo J, Ge Y, Hao L, Tan J, Li J, Feng X. On-road measurement of regulated pollutants from diesel and CNG buses with urea selective catalytic reduction systems.Atmospheric Environment, 99: pp.1-9, 2014.

[4] LIU Z, GE Y, JOHNSON K C, et al. Real-world operation conditions and on-road emissions of Beijing diesel buses measured by using portable emission measurement system and electric low-pressure impactor. Sci Total Environ, 409(8): pp.1476-1480,2011.

[5] FU M, GE Y, WANG X, et al. NOx emissions from Euro IV busses with SCR systems associated with urban, suburban and freeway driving patterns. Sci Total Environ, 452: pp.222-226, 2013.

[6] Beijing municipal environmental protection bureau, DB11/ 965-2013 Limits and Measurement Method of Emissions from Heavy Duty Vehicle (PEMS Method), Beijing 2013

[7] MARK A. DEARTH J W B, ALEX COLVIN, CHRISTINE GIERCZAK, STEVE KABERLINE AND TOM KORNISKI. SemtechD: The Chassis Roll Evaluation of a Commercial Portable Emission Measurement System (PEMS). SAE TECHNICAL PAPER SERIES, 2005-01-0673. 